AGRARIS: Journal of Agribusiness and Rural Development Research

Vol. 4 No.1 J anuari -J uni 2018
WIDODO, SITI YUSI RUSIMAH, NOVITA CHOIRUNISA

Department of Agribusiness

Universitas Muhammadiyah Yogyakarta

widodo@umy.ac.id

\section{Factors Affecting to Consumers' Attitude towards Halal Label on Nugget and Sausage Packaging: A Case Study on Housewives at One Residential in Yogyakarta City}

https://doi.org/10.18196/agr.4158

\begin{abstract}
Halal status of meat products is a credence attribute which is not visible and cannot be verified by consumers. Therefore, halal label is an important cue for consumers ab out the halal meat product. This study aimed to measure the consumers' attitude and to clarify the demographic and psychological factors that affected the consumers' attitude towards halal label on nugget and sausage packaging. The data of this study was collected in 2016 at one residential in Yogyakarta City. Meanwhile, respondents of 50 Muslim housewives were selected through simple random to fill out the selfadministered questionnaire. To measure consumers' information was used a 5 Likertscale of statement. While a binary logistic regression model was employed to analyse the effects of the demographic and
\end{abstract}

psychological factors on consumers' attitude. The results showed that respondents perceived the label of council of certification, Arabic script of halal, and food ingredient could very well indicate the halal nature of nugget and sausage. Furthermore, respondents tend to use them to investigate the halal nature. The demographic factor which affected the variation of consumers' attitude towards halal label was households' expenditure of food, meanwhile the psychological factor which affected the variation of consumers' attitude towards halal label was family habit of purchasing halal foods. Based on this results can be concluded that the respondents of housewife strongly believe on halal label on nugget and sausage packaging but they do not examine thoroughly. Respondent of housew ife's attitude tow ard halal label improved due to an increasing on households' expenditure on food and a well family habituation.

Key words: attitude, consumers, halal label, meat product

\section{INTRODUCTION}

Indonesia's halal food sector has developed dramatically. In fact, the number of companies and products which were certified halal by the Indonesian U lema Council (MUI) has increased sharply. H alal certified products (food and nonfood) increased from 32,889 in 2012 to 114,262 in 2016 (Lembaga Pengkajian Pangan 0 bat obatan dan Kosmetika M ajelis U lama Indonesia, 2018). TheH alal market in Indonesia represents U S $\$ 78.5$ billion (Ratanamaneichat \& Rakkarn, 2013). M eanwhile, in 2020, Indonesian population is projected to be 271 million (BPS Statistics Indonesia, 2013), with over $85 \%$ of the population are Muslims. Thus, it is a huge potential market for halal products.

$\mathrm{H}$ alal is a code of conduct which is permitted by law of I slam and it applies to every activity carried out by a M uslim (M ohammed, Rezai, Shamsudin, \& Chiew F.C., 2008). It also refers to food that are permissible for M uslim to consume (Ambali \& Bakar, 2013). All foods are considered halal except pork and its by-products, animals improperly slaughtered or are dead before slaughtering, animals killed in the name of other than God. Moreover, non-halal 
products include drinksthat intoxicate, carnivorous animals, birds of prey, land animals without external ears, blood and blood by-products, and foods that are contaminated with any of the above mentioned products (Riaz \& Chaudry, 2004). Animals' meat must be from animal slaughtered in the Islamic manner and must not be dedicated to anyone but Allah and must be obtained through lawful manner (Said, H assan, M usa, \& Rahman, 2014).

The processed food that is purchased by M uslim must be halal. H ence, M uslim consumers are found to be very particular and sensitive about the halal of processed foods they purchased (M ohammed, Rezai, Shamsudin, \& C hiew, 2008). $\mathrm{H}$ alal status of meat product is a credence attribute which cannot be ascertained by the consumer, even upon consumption of the meat. The halal meat product chain begins from the farm to the table that all characteristics of these meat products are not visible and cannot be verified by the consumer (N akyinsige, Che Man, \& Qurni, 2012). Therefore, halal label is an important cue for consumers about the halal meat product (W einrich \& Spiller, 2016). Food labels would provide information and choice to Muslim consumers (Adams, 2011). M oreover, the halal labelling that is certified by authorized council would protect M uslim consumersfrom non-halal foods (H idayat \& Siradj, 2015; Syafrida, 2017).

It is clear that there is a significant association between label use and thequality of products purchased. For example, nutrition label use leads to healthier food purchases $(\mathrm{Ni}$ M hurchu, Eyles, Jiang, \& Blakely, 2018). The effects of label on quality perception and acceptability of chicken meat be come more proven when consumers understood and trusted the label claims (Samant \& Seo, 2016). A multi-tevel labelling system achieves more products that are purchased by consumers (W einrich \& Spiller, 2016).

The findings of the previous studies show that halal food consumption behaviour has been identified. Consumers are aware about theimportant of the official's halal logo on food product packaging even though they evaluate all kinds of halal clue (M ohammed, Rezai, Shamsudin, \& C hiew, 2008). $M$ oreover, halal consumption behaviour is supported by halal label and health related reasons (Ambali \& Bakar, 2013). Attitudes towards halal products were important antecedents of intention to purchase halal products and mediated the subjectivenorm (Briliana\& M ursito, 2017). Perceived healthiness of existing products was positively associated with the purchase intention of processed meats (Shan et al., 2017).

Some studies have revealed the effect a number of factors on halal food consumer behaviour. In case of $\mathrm{M}$ alaysia halal food, it was found that different nationalities have different perception towards halal food products, moreover it shows that the consumers' perception and their level of knowledge and religiosity differs (G runert, H ieke, \& W ills, 2014; Said, H assan, M usa, \& Rahman, 2014). Knowledge and awareness about halal foods, good manufacturing and practices will bring about trustworthiness on food products with halal logo (M ohammed, Rezai, Shamsudin, \& Chiew, 2008). Other studies show the roles of religiousity and cultural-value orientation toward intentions of M uslim consumers to buy halal food (A mbali \& Bakar, 2013; Said, Hassan, M usa, \& Rahman, 2014; Jamal \& Sharifuddin, 2015) but not significant predictors of the purchase intention for enriched processed meat (Shan et al., 2017). U nderstanding and use of selected label on food products are affected by demographic characteristics (Grunert, H ieke, \& W ills, 2014).

All the aforementioned studies describe consumers' behaviour on halal food, attitude toward halal foods and factors that affect their attitude. M oreover, some studies of attitude toward halal logo and label on food product have been conducted, but there is not study about consumers' attitude towards halal label of meat product. $\mathrm{H}$ alal logo is logo that indicate product of which has been claimed as halal product by producer, and halal label means written information on packaging that denotes halal meat products, such as halal registration number, council that certified it, the A rabic script of halal, food ingredient, and the brand name. This study aimed to measure the consumers' attitude toward halal label written on food packaging of nugget and sausage. In addition, this study is to clarify the demographic and psychological factors that effected to consumer attitude toward halal label. It was hypothesized that the demographic factor, i.e. religiousness, housewife age, housewife education level, and households' expenditure of food, and psychological factor, i.e. family habit and motive of consumption affect to consumers' attitude toward halal label.

\section{METHODS}

The data of this study was collected in 2016 at one residential in Yogyakarta City. This residential is inhabited by 120 middle upper class multi-cultural households, and most of them are M uslim. Most of the housewives at the residential $(80 \%)$ are worker so they have less time to serve foods for the family members. Respondents of this study were 50 M uslim housewives whom were selected through the simple random to fill out the self-administered questionnaire. Q uestions that were asked to the housewives were affective and conative components of attitude ( $\mathrm{Ortiz}, \mathrm{C}$ hiu, Wen-Hai, \& 
H su, 2017) toward halal label on nugget and sausage packaging, nugget and sausage consumption, family habit of purchasing official halal labelled food, motive of consumption, and religiousness of the family members.

$\mathrm{H}$ alal label on nugget and sausage packaging was adapted from the concept that has been used on study of nutrition label information (Higginson, Kirk, Rayner, \& D raper, 2002) and on study of orange juice and nectar (Ferrarezi, M inim, Santos, \& M onteiro, 2013). In this study, the halal label encompassed with the halal registration number, council that certified it, the Arabic script of halal, food ingredient, and the brand name. The affective component of attitude was expressed with 5 statements on each halal label of "I perceive that the registration number/ council that certified it/ the A rabic script of halal/ food ingredient/ the brand namewritten on the product packaging can indicate the halal nature of sausage and nugget". M eanwhile, the conative component of attitude on each halal label was expressed with 5 statements of "I tend to use the registration number/ council that certified it/ the Arabic script of halal/ food ingredient/ the brand name written on the product packaging to indicate the halal nature of sausage and nugget". Referring to (Kulas, Stachowski, \& H aynes, 2008), a Likert scale of 1 (representing absolutely disagree) to 5 (representing absolutely agree) was used to measure the respondents' statement of affectiveand conative commponent of attitude. Respondent' attitude was a composite variable that was defined as the average of affective and conative component, thus the respondents' attitudescore on the halal label runsfrom 1 to 5 . Based on the average score, respondents' attitude toward halal label are categorized in 3 levels, i.e low (score 1 - 2.33); fair (score 2.34 - 3.66); and high (score 3.67 - 5).

A 5 scale runs from 1 (representing strongly disagree) to 5 (representing strongly agree) is also used to measure some independent variables, namely: i) family habits, was defined as a statement of "I come from a family that inculcates the habit of consuming halal products"; ii) the motive of consumption was defined as a statement of "I buy sausage and naget to provide varied sidedishes"; iii) religiousness as measured by three statements of "I attended recitals held in the neighborhood / I attended tahlilan group / I attended a prayer in congregation in mosque". Thus, the scores for family habits and motive of consumption will run from 1 to 5 ; while the average religiousness score will run from 1 to 5 . In addition, the score is used to measure housewife education level, by giving score of 1 for elementary education, score of 2 for junior high school education, score of 3 for high school education, and 4 of for higher education. 0 ther independent variables i.e. housewife age was measured in years; and households' expenditure of food was measured in Rupiah per month.

Both descriptive and regression analyses were performed to analyse the information collected from the samples. The descriptive analysis was used to analyse the housewife respondents' demographic and psychological characteristics. M eanwhile, a binary logistic regression model (M enard, 2011) was used to predict the influence of family habit, religiousness, housewife age, housewife education level, motive of consumption, and households' expenditure of food on consumers' attitude. The mathematical model, as it was used by (Aufanada, Ekowati, \& Prastiwi, 2017; W idodo, Kamardiani, $\&$ Rahayu, 2016), is written as:

$$
\begin{gathered}
\ln \left(\frac{P}{1 P}\right)=\beta_{0}+\beta_{1} H \text { bt }+\beta_{2} R \lg +\beta_{3} \text { Age }+ \\
\beta_{4} E d u+\beta_{5} \text { M ot }+\beta_{6} \operatorname{Exp}
\end{gathered}
$$

$P$ was consumer's attitude $(P=1$, if housewife's attitude was high, $P=0$, if housewife's attitude was fair or low), $H$ bt was family habit (score), Rlg was religiousness (score), A ge was housewife age (year), Edu was housewife education level (score), M ot was motive of consumption (score), and Exp was households' expenditure of food (IDR per month).

$M$ aximum likelihood was implemented to estimate the regression coefficients, and the purpose this estimation was to find the optimal combination of independent variables to maximize consumers' attitude. Chi-squared distribution was used to test the different between their log-ikelihood of the null model and the hypothetical model. M oreover, the W ald test was used for testing the significance of individual independent variables.

\section{RESULTS AND DISCUSSION \\ DEM OGRAPHIC PROFILE OF RESPONDENTS}

All respondents were hou sewives and most of them (86\%) were in the level of productive age (see Table 1). This data shows that the residential has more productive age of housewives compared to the female population of Yogyakarta C ity in 2013. A pproximately $58 \%$ of the respondents' family has four to five members. In addition, more than $75 \%$ of the respondents were employed and $68 \%$ of them had tertiary education. This data shows that the housewives at the residential were well educated and have salary to contribute the familyincome. Thus, the result indicates that the households at the residential are considered as the middle upper class family. 
TABE1 THEDMOPAPHCPPOHEOFESODENISCFOAFWE, IN $2016(N=50)$

\begin{tabular}{|c|c|}
\hline Desciption & Percetage $(\%)$ \\
\hline \multicolumn{2}{|l|}{ AcF } \\
\hline $23-32$ & 26 \\
\hline $33-42$ & 18 \\
\hline $43-52$ & 42 \\
\hline $53-2$ & 14 \\
\hline \multicolumn{2}{|l|}{ Haschddstemtiter } \\
\hline $1-3$ & 42 \\
\hline 4- 5 & 58 \\
\hline \multicolumn{2}{|l|}{ Ceaptiar } \\
\hline Cuil severt & 22 \\
\hline Pivitesetor & 36 \\
\hline Seff-enployed & 18 \\
\hline Hoseive & 24 \\
\hline \multicolumn{2}{|l|}{ Edcationled } \\
\hline Piimæyojuvioushod & 2 \\
\hline Hghshod & 30 \\
\hline Hgheredration & 68 \\
\hline Todd & 10 \\
\hline
\end{tabular}

RESPONDENTS' FAMILY HABIT AND MOTIVE OF CONSUMPTION

Respondents of haousewife came from family with various habit on halal food consumption. Some respondents of housewife came from families who carefully paid attention to halal nature when buying and consuming processed food, but others paid less attention to it. The most of respondents of housewife camefrom families who paid enough attention to halal nature when buying and consuming processed food. Family habit score of 2.96 (Table 2) showed that the respondent's family habit on buying and consuming processed food was not absolutely good. M eanwhile, this research finding showed that purchase on sausage and nugget of the respondents of housewife's was quite motivated to provide varied side dishes (Table 2).

\section{TABE2 LESROPIONGFEPONDNIS FAMIYHABTANDMOINEG} COBSMPION

\begin{tabular}{lc}
\hline Psychogica fato & Sat \\
\hline Fanilyhabit & 296 \\
MativeofCosumpion & 288 \\
\hline \multicolumn{2}{c}{ Note: The score range was $1-5$}
\end{tabular}

RESSPONDENTS' CONSUMPTION AND PURCHASE OF NUGGET AND SAUSAGE

Respondents of housewife usually buy sausages for snacks, side dishes, or as one of main course ingredients of soup. $M$ ean while, nuggets are commonly consumed as a snack or a side dish. Respondents of housewife purchased nuggets and sausages once for few days. Some brand names of sausage were usually purchased by housewife, such as Vi, Sn, and $C h$. $\mathrm{O}$ the other hand, the brand names of nugget that were normally purchased by the housewives were $\mathrm{Ch}, \mathrm{Fs}, \mathrm{Bl}, \mathrm{Sg}$, and the others are without a brand name. The majority of nuggets' brand name that was purchased was $\mathrm{Sg}$. A bout $44 \%$ of housewife respondents purchased nuggets with the brand name Sg (see Table 3).

\section{TABE3 FESONEISGFOAFWIESPRCHEANDCOBMPIIONON SALACEANDNGCE, INZ016( $N=50)$}

\begin{tabular}{|c|c|}
\hline Descriptiar & Presetase(\%) \\
\hline \multicolumn{2}{|c|}{ Bandraneofsasage } \\
\hline $\mathrm{Vi}$ & 34 \\
\hline Sn & 34 \\
\hline Ch & 36 \\
\hline \multicolumn{2}{|c|}{ Bandnaneofngget } \\
\hline Ch & 10 \\
\hline Fs & 28 \\
\hline $\mathrm{Bl}$ & 22 \\
\hline $\mathrm{Sg}$ & 44 \\
\hline NBBand & 10 \\
\hline
\end{tabular}

M odern markets have become the favourite place to purchase sausages and nuggets. H ou sewives or other familymembers usually purchased sausages and nuggets together with other daily needs. M eanwhile, only the housewives or the family servant purchased sausages and nuggets at traditional markets, depots, or meat product shops.

From the previous discussion, it can be concluded that, there are varieties of sausage brand names and the majority was purchased in the modern markets. All purchased brand names of sauage were certified by the authorized council and was written official halal label. Sg was the one of the favourite purchased brand names of nugget. All purchased nuggets were certified by the authorized council and was labelled official halal label except the nuggets which have no brands.

\section{AFFECTIVE AND CONATIVE COMPONENT OF ATTITUDE TO-} WARD HALAL LABEL

This study uses the affectiveconative of the tri-component attitude model (D wiastuti, Shinta, \& Isaskra, 2012) to investigate consumers' attitude toward the halal label written on product packaging. Affectiveis an individual's subjective perception of positive or negative emotions and feelings of attitude generated by interactions with some halal labels, while conative is the final behavioural intention based on an individual's perception and feeling (O rtiz, Chiu, Wen-Hai, \& H su, 2017). 


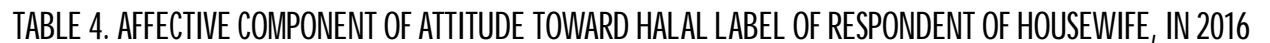

\begin{tabular}{|c|c|c|c|}
\hline Stenent dfaffetive & Menscare & $\begin{array}{l}\text { Scoedtaimet } \\
(\%)\end{array}$ & Getegory \\
\hline 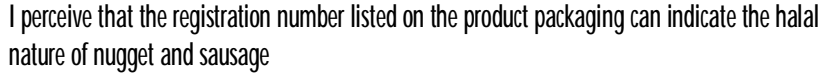 & 3.28 & 57.0 & Fär \\
\hline 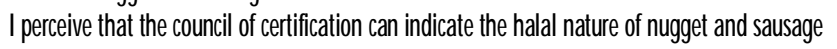 & 4.3. & $83 \mathrm{C}$ & $\mathrm{Hg}$ \\
\hline 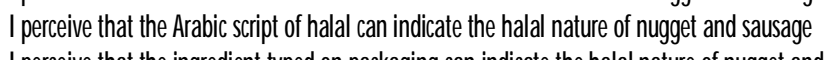 & $4.4 \varepsilon$ & $87 . \mathrm{C}$ & $\mathrm{Hg}$ \\
\hline 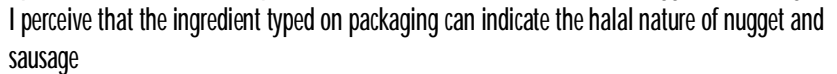 & 4.42 & 855 & $\mathrm{Hgh}$ \\
\hline 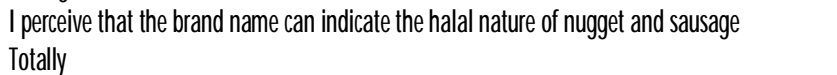 & $\begin{array}{l}25 \varepsilon \\
3.91\end{array}$ & $\begin{array}{l}52 C \\
72 C\end{array}$ & $\begin{array}{l}\text { Fair } \\
\mathrm{Hg}\end{array}$ \\
\hline
\end{tabular}

There were five items of halal label that were investigated in this study; they include registration number, council of certification, the Arabic script of halal, food ingredient, and the brand name. The council of certification and Arabic script of halal can be read on the official logo of halal that was written on each packaging. The registration number of halal is an official number which anyone has an access to check the product's name, the production company, and the validation date on the official halal council website. Respondents perceived that council of certification, A rabic script of halal, and food ingredient could very well indicate the halal nature of sausages and nuggets. M eanwhile, respondents perceived that both the registration number and thebrand name can fairly indicate the halal nature (Table 4). O ne can concludethat respondents of housewife absolutely believe in the official logo of halal without checking the validity of the logo written on the packaging. M oreover, it can be concluded that respondents of housewife feel confident about the information which was company written on the nuggets and sausages packaging.

Respondents of housewife tend to use the written ingredient information on the packaging highly to indicate the halal nature of sausages and nuggets. Respondents of housewife particularly refer to the raw ingredients such as the use of beef and chicken written on ingredient information to indicate the halal nature of the meat products. All purchased sausages were made from chicken or beef, while nuggets that were purchased by the respondents of housewife were made from chicken. Furthermore, respondents of housewife tend to use the A rabic script and council of certification to investigate the halal nature of the sausages and nuggets, but they did not use the registration number. Actually, the respondents of housewife are able to verify the halal label of one product on official site of Assessment Institute for Foods, D rugs and Cosmetics (it is known in the Bahasa Indonesia as Lembaga Pen gkajian Pangan, O bat-obatan dan Kosmetika/ LP-PO M ) properly by entering the registration number. $\mathrm{H}$ owever, this study shows that the respondents of housewife did not tend to use it to denote the halal product. It can be concluded that the consumers care to all the written ingredients information on the packaging, the official logo given by the council of certification, and the typical A rabic script of halal, however they less care to the registration number and brand name.

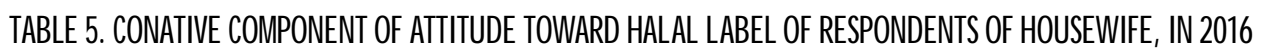

\begin{tabular}{|c|c|c|c|}
\hline Stederetof condive & MenState & Scoredtaimet(\%) & Categor \\
\hline 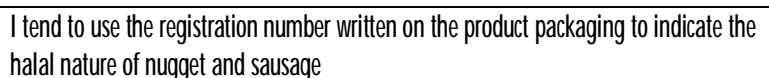 & 276 & 44.0 & Fär \\
\hline $\begin{array}{l}\text { I tendto sethecandl of cetifictionlistedontheprodit padkagingtoindcde } \\
\text { thehdal natureof nggt andsasage }\end{array}$ & 390 & 725 & Hgh \\
\hline $\begin{array}{l}\text { I tendtousetheAdbicsaipt listedonthepodit padkagingtoindcatethehdal } \\
\text { ratureofngget andsasage }\end{array}$ & 4.18 & 79.5 & Hgh \\
\hline $\begin{array}{l}\text { I terdtolokdtheingedetswitten onthepodit pedkaingtoindcatethe } \\
\text { hald natureofnggetandsasage }\end{array}$ & 434 & 83.5 & Hgh \\
\hline I tendtousethebandranetoindcdetheh da ntureofngget andsasage & $2 \pi$ & 445 & Fäi \\
\hline Tath & 35 & $64 . \varepsilon$ & Fäi \\
\hline
\end{tabular}


FACTORS AFFECTING THE ATTITUDE TOWARD HALAL LABEL

Respondents' attitude toward halal label was affected by some factors. A binary logistic regression was applied to explain such factors that affected the respondents' attitude toward halal label.

\section{TABE6 THEFEUTCFBNAPVLOSSTICFEOPESONONATITLE TOAAPDHAALABH}

\begin{tabular}{|c|c|c|c|c|}
\hline Veriade & $\beta$ & WAd & $\mathrm{p}$ & $\operatorname{Ex}(\beta)$ \\
\hline Fanilyhabt & 6377 & 454 & 0.033 & 587.943 \\
\hline Ptigianess & -2512 & 176 & 0.184 & . 081 \\
\hline Hasevifeage & -0.065 & 1223 & 0.269 & .937 \\
\hline Hasenifeedrationled & -0.300 & 0.06 & 0.795 & .741 \\
\hline Mativeofcorsuntion & -2808 & 1108 & 0.294 & .060 \\
\hline 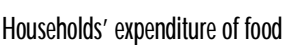 & 0,005 & 3047 & 0.081 & 1005 \\
\hline Constat & -8861 & & & \\
\hline
\end{tabular}

Nagelkerke R square $=0.7777$

Chi square $=43,684 p=0.000$ Overall percentage $=92 \%$

The resulted $\mathrm{Chi}$-square was 43.684 with degree of free dom equals to 6 and p-value less than 0.001 (Table 6). It suggested that there was adequatefit of the data to the model. This finding implied that there was at least one of the variables of family habit, religiousness, housewife age, housewife education level, motive of consumption, and households' expenditure of food was significantly related to the variation of consumers' attitude towards the halal label.

The overall accuracy of these independent variables to predict consumers' attitude toward halal label was both $92 \%$ of positive and negative prediction using cut value of 0.5 . It means that $92 \%$ of both negative and negative cases could be predicted correctly by the variables used in this model. For testing individual variable, the estimated coefficients of logistic regression were assessed by the Wald test. The variable of family habit and households' expenditure of food affected significantly to the variation of respondents' attitude towards the halal label. It means that a better family habit and higher households' expenditure of food improved the consumers' attitude toward halal label. However, the variable of religiousness, housewife's age, housewife's education level, and motive of consumption did not affect significantly to the variation.

All human have habitual behaviours that allow to carry out essential tasks very easily (W aller Jr., 1988). H abits keep us doing what we have always done, despite our best in tensions to act otherwise (Neal, Wood, \& Q uinn, 2006). In any case if a habit is routine, if the circumstances for which the habit developed disappear, the habit should not persist (Waller Jr., 1988). Research address that habits drive consumer choices (N eal, Wood, \& Q uin, 2006), however practice is the perfect form of drill (Waller Jr., 1988).

This study revealed a well habituation and attitude toward halal label but respondents of housewife just believe on official halal certification logo written on packaging. Respondents of housewife did not use registration number to check the authenticity of the logo of halal. The halal registration number consists of 12 numbers which was small size listed on each packaging product item. Although, respondents housewife can use their smartphone to check it, but she met difficulties and spend much minutes to enter a lot of numbers. This finding indicates that respondents of housewife thoroughly belives to the official certification logo, and this finding is in contrary to $M$ alaysia that consumers evaluateall kinds clue of halal (M ohammed et al., 2008). An explanation of this research finding was a lack knowledge on their religion especially on practical knowledge of halal food (Ambali \& Bakar, 2013). Another explanation was that habituated individuals were more intuitive responses with regard to consumption of the involved product category (Tendero \& Bernabéu, 2005; O Isen et al., 2008).

This study found that families' best habit practice on purchasing the halal label food improved the attitude of housewife. Parents played central roleon their families' habit and parental control to children has been associated to habit of their children. This study showed that respondents of housewife who come from family that have a good habit on purchasing halal products have a better attitude toward halal label. Respondents of housewives whom are accustomed to purchased halal labeled products tend to pay attention to various label that indicate the halal nature of the nugget and sausage and use it as a consideration in purchasing the product. This finding was in line with previous studies of family well habituation. For example, controlling of parents on which television programs were watched by children would lead nutritional behaviour ( $\mathrm{N}$ ascimento \& Fiates, 2013). Moreover, young consumers' were less ability to implement such knowledge into the reality of their daily food behaviour (Brown, M cilveen, \& Strugnell, 2000) especially on urban household (Y1ld1r1m \& C eylan, 2008).

H ouseholds' expenditure indicates economic well-being, and it is a better measure of the family permanent income (M eyer \& Sullivan, 2011). The variable of household expenditure related to family choice of food purchased and food knowledge (Liu \& N iyongira, 2017). Religious knowledge or 
belief is the best guide to determine one's food consumption because several religions impose food restrictions (A mbali \& Bakar, 2013).

This research finding reveal s that an increasing on households' expenditure of food leads a better respondents of housewife's attitudetoward halal label. A higher households' expenditure of food means a more choice on purchased food and reveals higher family well-being. An explanation of this research finding was that a higher households' expenditure of food has a more chance to avoid non halal food by carefully selected halal food. Not only religious motive, another explanation was that \%alal food consumption related to health issues. This research finding supported the past research. It was found that upper and middle class have increase quality of food intake (Y $1 \mathrm{ld} 1 \mathrm{r} 1 \mathrm{~m} \&$ C eylan, 2008; Khattak \& A kram, 2012), and members of different groups are likely to make purchase decisions which are influenced by their identity (Schiffman \& Kanuk, 2007).

Paradigm of food was radically restructured from "food as health" to "food as well-being". The concept of food wellbeing (FW B) is defined as a positive psychological, physical, emotional, and social relationship with food at both individual and societal levels (Block et al., 2011; Ferriss, 2002). The concept of FW B was looked at as happiness (subjective well-being), or respectively as material well-being (material utility) and as psychological well-being (psychological utility) (D'Acci, 2011). Consuming halal food must be abided by all M uslims, and according to the concept of FW B, consumption of halal food indicates the family well-being (N oor, Gandhi, Ishak, \& Wok, 2014).

Formal education, religious activities followed by respondents of housewife, as well as the daily interactions of housewives do not provide knowledge of procedures on the selection of halal food products including meat products. Therefore, higher education of housewives, better religious activity and age do not raise awareness of the housewife on the role of label to indicate halal food that will be purchased. This fact causes the education level of housewife, religiousness, and age of housewife do not affect to consumers' attitudes toward halal label. M otivation of housewife to provide more varied food without followed by a good level of knowledge about halal label also makes the motivation has no effect on consumer attitudes toward halal label. Previous research explains this finding that exposureto information of halal food that was received by consumers determinate the awareness about halal food consumption (Ambali \& Bakar, 2013), furthermore consumers will change their purchasing of food product as a result of the information (Koç\& C eylan, 2009).

\section{CONCLUSION}

$\mathrm{H}$ alal label is an important cue for M uslim which denote the halal meat product due to halal status of meat product cannot be ascertained by consumer. This research conclude that the respondents of housewife strongly believe on halal label on nugget and sausage packaging but they do not examine thoroughly. Respondent of housewife's attitude toward halal label improved due to an increasing on households' expenditure on food and a well family habituation. Based on this cases, producers of meat product are strongly suggested to certified their product to the official council and clearly write the halal logo and registration number on the product packaging. The other hand, the Muslim community needs an upgrading on complete insight of halal label of meat products which will be purchased.

\section{REFERENCES}

Adams, I. A. (2011). Globalization/: Explaining the dynamics and challenges of the halal food surge. Intelectual Discourse, 19, 123-145.

Ambali, A. R., \& Bakar, A. N. (2013). \$alâl food and products in Malaysia/ : People' $s$ awareness and policy implications. Intelectual Discourse, 21(1), 7-32.

Aufanada, V., Ekowati, T., \& Prastiwi, W. D. (2017). Kesediaan Membayar Produk Sayuran Organik di Pasar Modern Jakarta Selatan. AGRARIS: Journal of Agribusiness and Rural Development Research, 3(2), 6775. https://doi.org/10.18196/ agr.3246

Block, L. G., Grier, S. A., Childers, T. L., Davis, B., Ebert, J. E.., Kumanyika, S., ... van Ginkel Bieshaar, M. N.. (2011). From Nutrients to Nurturance: A Conceptual Introduction to Food Well-Being. Journal of Public Policy \& Marketing, 30(1), 5-13. https://doi.org/10.1509/jppm.30.1.5

BPS Statistics Indonesia. (2013). Indonesia Population Projection 20102035. Jakarta: BPS - Statistics Indonesia.

Briliana, V., \& M ursito, N. (2017). Exploring antecedents and consequences of Indonesian Muslim youths' attitude towards halal cosmetic products: A case study in Jakarta. Asia Pacific Management Review, 22, 176-184. https://doi.org/10.1016/j.apmrv.2017.07.012

Brown, K., Mcilveen, H., \& Strugnell, C. (2000). Nutritional awareness and food preferences of young consumers. Nutrition $\&$ Food Science, 30(5), 230-235. https://doi.org///doi.org/10.1108/ 00346650010340963

D'Acci, L. (2011). Measuring Well-Being and Progress. Social Indicators Research, 104, 47-65. https://doi.org/10.1007/s1125-010-9717-1

Dwiastuti, R., Shinta, A., \& Isaskra, R. (2012). Ilmu Perilaku Konsumen. Malang: UB Press.

Ferrarezi, A., Minim, V. P., Santos, K. M. dos, \& Monteiro, M. (2013). Consumer attitude towards purchasing intent for ready to drink orange juice and nectar. Nutrition \& Food Science, 43(4), 304-312. https://doi.org///doi.org/10.1108/NFS-03-2012-0021

Ferriss, A. L. (2002). DOES MATERIAL WELL-BEING AFFECT NON-MATERIAL WELL-BEING? Social Indicators Research, 66(1), 275-280.

Grunert, K. G., Hieke, S., \& Wills, J. (2014). Sustainability labels on food products: Consumer motivation, understanding and use. Food Policy, 44, 177-189. https://doi.org/10.1016/j.foodpol.2013.12.001

Hidayat, A. S., \& Siradj, M. (2015). SERTIFIKASI HALAL DAN SERTIFIKASI NON HALAL. Ahkam, 15, 199-210. 
Higginson, C. S., Kirk, T. R., Rayner, M. J., \& Draper, S. (2002). How do consumers use nutrition label information? Nutrition \& Food Science, 32(4), 145-152. https://doi.org/10.1108/00346650210436253

Jamal, A., \& Sharifuddin, J. (2015). Perceived value and perceived usefulness of halal labeling/: The role of religion and culture. Journal of Business Research, 68, 933-941. https://doi.org/10.1016/ j.jbusres.2014.09.020

Khattak, M. M. A. K., \& Akram, Z. (2012). Socio economic class affects nutritional status but not food habit. Nutrition \& Food Science, 42(3), 164-172. https://doi.org/10.1108/00346651211228450

Koç, B., \& Ceylan, M . (2009). Consumer-awareness and information sources on food safety: A case study of Eastern Turkey. Nutrition \& Food Science, 39(6), 643-654. https://doi.org/https:// doi.org/10.1108/ 00346650911002977

Kulas, J. T., Stachowski, A. A., \& Haynes, B. A. (2008). Middle response functioning in likert-responses to personality items. Journal of Business and Psychology, 22(3), 251-259. https://doi.org/10.1007/ s10869-008-9064-2

Lembaga Pengkajian Pangan Obat obatan dan Kosmetika Majelis Ulama Indonesia. (2018). Statistik Sertifikasi Halal Indonesia. Retrieved February 16, 2018, from http://www.halalmui.org/muil4/index.php/main/ go_to_section/59/1368/page/1

Liu, A., \& Niyongira, R. (2017). Chinese consumers food purchasing behaviors and awareness of food safety. Food Control, 79, 185-191. https://doi.org/10.1016/j.foodcont.2017.03.038

Menard, S. (2011). Applied Logistic Regression Analysis. Thousand Oaks: SAGE Publications, Inc. https://doi.org///dx.doi.org/10.4135/ 9781412983433

Meyer, B. D., \& Sullivan, J. X. (2011). Viewpoint/: Further results on measuring the well-being of the poor using income and consumption. The Canadian Journal of Economics, 44(1), 52-87.

Mohammed, Z., Rezai, G., Shamsudin, M. N., \& Chiew F.C., E. (2008). Halal logo and consumers ' confidence/: What are the important factors/ ? Economic and Technology Management Review, 3, 37-45.

Nakyinsige, K., Che Man, Y. Bin, \& Qurni, A. (2012). Halal authenticity issues in meat and meat products. Meat Science, 91(3), 207-214. https://doi.org/10.1016/j.meatsci.2012.02.015

Nascimento, A., \& Fiates, G. (2013). A qualitative study of Brazilian children's habits. Nutrition \& Food Science, 43(6), 527-534. https:// doi.org/10.1108/NFS-08-2011-0083

Neal, D. T., Wood, W., \& Quinn, J. M. (2006). Habits - A repeat performance. Current Directions in Psychological Science, 15(4), 198-202. https://doi.org/10.1111/j.1467-8721.2006.00435.x

Ni M hurchu, C., Eyles, H., Jiang, Y., \& Blakely, T. (2018). Do nutrition labels in $\mathrm{fl}$ uence healthier food choices/? Analysis of label viewing behaviour and subsequent food purchases in a labelling intervention trial. Appetite, 121, 360-365. https://doi.org/10.1016/j.appet.2017.11.105

Noor, N. M., Gandhi, A. D., Ishak, I., \& Wok, S. (2014). Development of Indicators for Family Well-Being in M alaysia. Social Indicators Research, 115(1), 279-318. https://doi.org/10.1007/sl 1205-012-0219-1

Olsen, S. O., Tudoran, A. A., Brunsø, K., \& Verbeke, W. (2008). Extending the prevalent consumer loyalty modelling: the role of habit strength. European Journal of M arketing, 47, 303-323. https://doi.org/10.1108/ M BE-09-2016-0047

Ortiz, J., Chiu, T.-S., Wen-Hai, C., \& Hsu, C.-W. (2017). Article information/:"Perceived justice, emotions, and behavioral intentions in the Taiwanese food and beverage industry. International Journal of Conflict M anagement, 28(4), 437-463. https://doi.org/https://doi.org/ 10.1108/IJ CM A-10-2016-0084

Ratanamaneichat, C., \& Rakkarn, S. (2013). Quality Assurance Develop- ment of Halal Food Products for Export to Indonesia. In Procedia Social and Behavioral Sciences (Vol. 88, pp. 134-141). Elsevier B.V. https://doi.org/10.1016/j.sbspro.2013.08.488

Riaz, M. N., \& Chaudry, M. M. (2004). Halal Food Production. Halal Food Production. Boca Raton: CRC Press. https://doi.org/10.1201/ 9780203490082.ch2

Said, M., Hassan, F., Musa, R., \& Rahman, N. A. (2014). Assessing Consumers ' Perception, Knowledge and Religiosity on Malaysia ' s Halal Food Products. In Procedia - Social and Behavioral Sciences (Vol. 130, pp. 120-128). Elsevier B.V. https://doi.org/10.1016/ j.sbspro.2014.04.015

Samant, S. S., \& Seo, H.-S. (2016). Quality perception and acceptability of chicken breast meat labeled with sustainability claims vary as a function of consumers ' label-understanding level. FOOD QUALITY AND PREFERENCE，49，151-160. https://doi.org/10.1016/ j.foodqual.2015.12.004

Schiffman, L. G., \& Kanuk, L. L. (2007). Consumer Behavior (9th ed.). Prentice-Hall: Person.

Shan, L. C., Henchion, M., Brún, A. De, Murrin, C., Wall, P. G., \& Monahan, F. J. (2017). Factors that predict consumer acceptance of enriched processed meats. Meat Science, 133, 185-193. https://doi.org/ 10.1016/.j.meatsci.2017.07.006

Syafrida. (2017). Sertikat Halal Pada Produk dan Minuman Memberi Perlindungan dan Kepastian Hukum Hak-Hak Konsumen Muslim. Adil: Jurnal Hukum, 7(2), 159-174.

Tendero, A., \& Bernabéu, R. (2005). Preference structure for cheese consumers: A Spanish case study. British Food Journal, 107, 60-73. https:/ /doi.org/10.1108/00070700510579144

Waller Jr., W. T.. (1988). The Concept of Habit in Economic Analysis. Journal of Economic Issues, 22(1), 113-126.

Weinrich, R., \& Spiller, A. (2016). Developing food labelling strategies/: Multi-level labelling. Journal of Cleaner Production, 137, 1138-1148. https://doi.org/10.1016/j.jclepro.2016.07.156

Widodo, W., Kamardiani, D. R., \& Rahayu, L. (2016). Minat Konsumen Terhadap Beras Organik di Daerah Istimewa Yogyakarta dan jawa Tengah. AGRARIS: Journal of Agribusiness and Rural Development Research, 2(2), 134-142. https://doi.org/10.18196/agr.2234

Y1ld1r1m, Ý., \& Ceylan, M. (2008). Urban and rural households' fresh chicken meat consumption behaviors in Turkey. Nutrition \& Food Science, 38(2), 154-163. https://doi.org/https://doi.org/10.1108/ 00346650810863037 